\title{
Risk Factors of Bacterial Resistance to Antibiotics in Internal Medicine and Hemodialysis Nephrology Services at the Edith Lucie Bongo Ondimba General Hospital
}

\author{
Gandzali-Ngabe Pierre Eric ${ }^{1}$, Ngoyi Ontsira Nina ${ }^{2}$, Gakosso Odou Philippe ${ }^{3}$, Loumingou Richard ${ }^{4}$ \\ ${ }^{1}$ Nephrology Hemodialysis, Édith Lucie BONGO ONDIMBA General Hospital, Oyo, Congo \\ ${ }^{2}$ Laboratory, Hospital and University Center of Brazzaville, Brazzaville, Congo \\ ${ }^{3}$ Laboratory, Édith Lucie BONGO ONDIMBA General Hospital Oyo, Brazzaville, Congo \\ ${ }^{4}$ Nephrology, Brazzaville Hospital and University Center, Brazzaville, Congo \\ Email: ngabe_eric@yahoo.fr
}

How to cite this paper: Eric, G.-N.P., Nina, N.O., Philippe, G.O. and Richard, L. (2021) Risk Factors of Bacterial Resistance to Antibiotics in Internal Medicine and Hemodialysis Nephrology Services at the Edith Lucie Bongo Ondimba General Hospital. Open Journal of Nephrology, 11, 9-20. https://doi.org/10.4236/ojneph.2021.111002

Received: January 4, 2021

Accepted: February 7, 2021

Published: February 10, 2021

Copyright $\odot 2021$ by author(s) and Scientific Research Publishing Inc. This work is licensed under the Creative Commons Attribution International License (CC BY 4.0).

http://creativecommons.org/licenses/by/4.0/

(c) (i) Open Access

\begin{abstract}
Introduction: Antibiotic resistance is a public health problem. It is due to multi-resistant bacteria (MRB). The objective of this study was to determine bacterial resistance to antibiotics in chronic renal failure at the Edith Lucie BONGO ONDIMBA general hospital (HGELBO). Patients, material and method: This was an analytical cross-sectional study conducted from January 1 to August 31, 2019 at the HGELBO. It concerned all patients admitted to the HGELBO with positive bacteriological samples. After a study of the sensitivity to isolated species, the patients were divided into two (02) groups: those MRB positive (+) and not MRB or negative (-). Epi Info software version 3.5.1 was used for the calculation of the rates and the comparison of the variables. The adjusted odds ratio (ORa) with a $95 \%$ confidence interval was used to measure the specific effect of each risk factor such as chronic kidney disease and diabetes, in order to rule out confounding factors. Multivariate analysis by binomial logistic regression was used. Results: There were 375 bacteriological samples from 258 patients, among them 247 patients with 235 positive samples or $63 \%$. The eleven (11) are healthy patients. The median age was 33 with extremes ranging from 16 to 90 . The female sex was predominant with a sex ratio of 0.6 . The majority of $\mathrm{MRB}+$ cases were found in internal medicine and nephrology with 12 cases (38.7\%) and hemodialysis with 4 cases (12.9\%). Urinary samples were in the majority with $74.5 \%$. Escherichia coli was predominant in $30.3 \%$. After studying the sensitivity to antibiotics of the 247 species included, 113 were $\mathrm{MRB}+$ and $134 \mathrm{BMR}-$ i.e. a frequency of
\end{abstract}


45.7\%. Methicilin-resistant Staphylococcus aureus (MRSA) was predominant (51.3\%). Multivariate logistic regression analysis showed that the main risk factor was antibiotic use (0Ra: 3.2 [1.9 - 5.4]; p-value $<0.01)$. Chronic renal failure and diabetes were not risk factors for carriage. The other risk factors identified were: hospitalization of more than 7 days (prolonged), $S$. aureus infection and male sex. Conclusion: Probabilistic antibiotic therapy leads to the selection of BMRs. Long hospital stays, male sex, and MRSA are risk factors or determinants of antibiotic resistance, but not chronic kidney disease.

\section{Keywords}

Risk Factors, Bacterial Resistance, Antibiotics, Chronic Renal Failure, General Hospital Edith Lucie BONGO ONDIMBA

\section{Introduction}

Bacterial resistance to antibiotics is the ability of certain bacteria to withstand a higher concentration of antibiotics than can be achieved in vivo during medical treatment [1]. Bacteria are said to be multi-resistant (MRB) when they accumulate acquired resistance to more than three families of antibiotics [2]. Antibiotic resistance is a public health problem. Bacterial resistance to antibiotics has increased alarmingly in recent years as newer antibiotics are less and less marketed [3] [4] [5] [6]. It is due to multi-resistant bacteria (MRB). Globally, resistance to C3Gs for Escherichia coli was 10.2\% in France; $15.6 \%$ in Portugal; $16.6 \%$ in Croatia and $29.5 \%$ in Italy [7] [8]. Resistance to ceftazidime for $P$. aeruginosa was $12.2 \%$ in France; $18.6 \%$ in Portugal; $19.5 \%$ in Croatia and $20.0 \%$ in Italy. The frequency of MRSA was $12.9 \%$ in France; $15.2 \%$ in Portugal; $28.5 \%$ in Croatia and $33.9 \%$ in Italy.

In Africa Mboyo, F.C. in 2016 in Morocco, reported 15\% resistance to E. coli; $5.6 \%$ for $P$. aeruginosa and 1.3\% for S. aureus [9]; Deguenovo et al. in 2016 in Senegal reported a frequency of $62 \%$ for EBLSE and $13 \%$ for P. aeruginosa [10].

In Congo, Moyen R. et al. in 2014 showed that beta-lactam resistance was 77.9\% for $S$. aureus; $44.4 \%$ for $P$. aeruginosa; and it ranged from 56.3 to 83.3 for Enterobacteriaceae [11]. However, the determinants of this resistance are not known in our region. The objective of this study was; in general to analyze the determinants of bacterial resistance to antibiotics at the Edith Lucie BONGO ONDIMBA general hospital (HGELBO), and specifically of: 1) Determine the frequency of multiresistant bacteria to HGELBO; 2) Describe in a comparative manner the socio-demographic and clinical characteristics of patients carrying multi-resistant bacteria $(\mathrm{MRB}+)$ and those carrying non-multi-resistant bacteria (MRB-) to HGELBO; 3) Determine bacterial resistance to antibiotics in chronic renal failure to HGELBO. 4) Identify the bacteria determining multidrug resistance to HGELBO antibiotics. 


\section{Patients, Material and Method}

This was an analytical cross-sectional study carried out from January 1 to August 31, 2019 at the HGELBO. Our study took place at the Edith Lucie BONGO ONDIMBA General Hospital (HGELBO) which is located in the Cuvette department and more precisely in the Oyo district. It is a public establishment that was put into service on March 10, 2017. It has 200 beds of which 148 are active with a monthly attendance of 255 patients. Our study was performed in the biomedical analysis laboratory. Patient recruitment was done on an outpatient basis, in inpatient departments or directly in the biomedical analysis laboratory. The target population consisted of any patient admitted to the HGELBO regardless of age, sex, origin, existence or not of an infectious pathology and in whom a bacteriological examination of the samples showed a positive culture for one of the following germs: Staphylococcus aureus, Enterobacteriaceae, Pseudomonas aeruginosa, Acinetobacter baumannii. We included patients with:

- gave their informed consent to the study.

- is the subject of the following samples: urine, vaginal secretions, put, puncture of joint fluid, hemodialysis catheter tip, probe tip.

- a positive culture.

Contaminations and epidemiological duplicates were excluded from our study.

The sampling was carried out from a simple random selection.

The sample size was calculated from Schlesselman's formula to ensure its representativeness. N: sample size; $\mathrm{r}: \mathrm{MRB}+/ \mathrm{MRB}-$ ratio that we have arbitrarily chosen $1 \mathrm{MRB}+$ for $3 \mathrm{MRB}-$ i.e. $\mathrm{r}=1 / 3 ; \mathrm{P}=(\mathrm{P} 0+\mathrm{P} 1) / 2=$ the average of the proportions; P0 - P1: the difference between the proportions. $\mathrm{P} 0=$ Proportion of affected in the subject group $(\mathrm{MRB}+)$ and $\mathrm{P} 1=$ Proportion of affected in the control group (MRB-). For $\mathrm{a}=0.05 ; \mathrm{Za}=1.65$; a being the type error $\mathrm{I}=$ Probability of wrongly saying that there is a difference in the two groups, therefore wrongly rejecting the null hypothesis. For $\mathrm{b}=0.1 ; \mathrm{Zb}=1.28$; $\mathrm{b}$ being the type II error $=$ Probability of wrongly saying that there is no difference in the two groups, therefore false admission of the null hypothesis. Numerical application: Given the fact that no study was available in Congo to use the variables, we used data from the case-control study carried out in Morocco in 2014 on the risk factors for infections with multidrug-resistant bacteria. At the level of the intensive care units, CHU Ibn Rochd, Casablanca [12] see Table 1. The parameter we considered was the antecedent of diabetes, i.e. $65 \%$ of patients presented an infection with ESBL+ E. coli $(\mathrm{P} 0)$ and $12 \%$ had ESBL- (P1) E. coli infection. We have $\mathrm{P} 1=0.12 ; \mathrm{P} 0=0.65 ; \mathrm{r}=1 / 3 ; \mathrm{Z} \mathrm{a}=1.65 ; \mathrm{Z} \mathrm{b}=1.28$. The calculation gives $\mathrm{N}$ = 29; hence we have a minimum size of $29 \mathrm{BMR}+$ and $87 \mathrm{MRB}-$. It concerned all patients admitted to the HGELBO with positive bacteriological samples. After a study of the sensitivity to the isolated species, the patients were divided into two (02) groups: those MRB positive (+) and not MRB or negative (-). Data collection was centered on a threefold survey: epidemiological, clinical and bacteriological 
Table 1. Comparison of our results zith those reported in 2014 in Morocco [12].

\begin{tabular}{ccc}
\hline & Majida H' serie & Our serie \\
\hline Sex & ORb [95\%] & ORb \\
Age & $1.58[0.5-4.6]$ & $2.01[1.20-3.37]$ \\
Diabetis & $3.19[0.83-12.2]$ & $3.55[2.09-6.04]$ \\
Old re hospitalisation & $3.8[1.12-14.6]$ & $2.10[1.22-3.62]$ \\
Time of hospitalisation & $8.5[1.1-69.54]$ & $2.48[1.47-4.18]$ \\
Vein catheter & $10.2[3.36-30.6]$ & $15[1.65-136.20]$ \\
New surgery & $2.08[0.39-11.2]$ & $3.95[1.39-11.24]$ \\
Antibiotic & $3.98[1.4-11.25]$ & $2.23[1.24-4.03]$ \\
Imipeneme & & $4.08[2.32-7.18]$ \\
Fluoroquinolones & $17.5[2.2-139.4]$ & \\
G3C & $6[1.26-28.4]$ & MRB+ \\
\hline
\end{tabular}

G3C: Third generation fluoroquinolones.

surveys. Epidemiological and clinical investigations: Before carrying out the investigations, the patients were informed about the study (theme, framework, advantages and objectives), the conditions of the examination and the sampling from an information sheet in order to obtain their informed consent. After obtaining their written and signed informed consent, patients were subjected to a standardized questionnaire to collect socio-demographic and clinical data. We conducted interviews in French (official language), Lingala (national language) according to the patient's preference. A code and an identification number were assigned to each patient in order to guarantee data confidentiality and anonymity. Bacteriological investigation: The bacteriological investigation was carried out respecting the three phases of the biological examination: the pre-analytical, analytical and post-analytical phases. The pre-analytical phase, after having collected the clinical information of the patients, the bacteriological samples were taken according to the recommendations in force [7] [8] [9]. The analytical phase of the samples was carried out respecting the following steps: macroscopic examination, cytological examination, bacteriological examination, cultivation, identification of the species and carrying out antibiograms. During the statistical analysis, Excel version 2016 software was used for the compilation of the database, the construction of tables and graphs. And Epi Info software version 3.5.1 was used for the calculation of the rates and the comparison of the variables. For the qualitative variables we used frequencies; for the quantitative variables we used the mean and standard deviation or the median and quartiles when the standard deviation was greater than one tenth of the whole part of the mean. The extreme values were specified. Pearson's chi-square test was used for the comparison of qualitative variables, when the conditions for its application were 
not met the exact Fischer test was used. The t-Student test was used for comparison of means. Mann Whitney test was used for comparison of medians. The test was considered statistically significant if the $\mathrm{p}$-value was less than 0.05 . The raw odds ratio $(\mathrm{ORb})$ with a $95 \%$ confidence interval was used to measure the association between carry at MRB and the explanatory variables. To do this, we performed a bivariate analysis between the dependent variable (sensitivity) with two modalities (MRB+ and MRB-) and the explanatory variables (independent variables or exposure variables) coded in binary mode. The adjusted odds ratio (ORa) with a 95\% confidence interval was used to measure the specific effect of each risk factor in order to rule out confounding factors (confusions that exist between BMR infection and certain independent variables). Multivariate analysis by binomial logistic regression was used. For each given variable, when the odds ratio was greater than 1 , then it multiplied the risk for a patient to be a carrier of BMR provided that his confidence interval does not contain the value 1 and that the $\mathrm{p}$-value is lower to 0.05 .

\section{Results}

There were 375 bacteriological samples from 258 patients. Among them 247 patients with 235 positive samples or $63 \%$. The eleven (11) healthy patients. The median age was 33 with extremes ranging from 16 to 90 . The female sex was predominant with a sex ratio of 0.6 . The internal medicine, nephrology and hemodialysis departments had more patients in hospital, 16 out of 31 , or $51.6 \%$. The majority of MRB+ cases were found in internal medicine and nephrology with 12 cases $(38.7 \%)$ and hemodialysis with 4 cases $(12.9 \%)$ see Table 2 . Urinary samples were in the majority with $74.5 \%$. The germ Escherichia coli predominated in $30.3 \%$. See Table 3 . After the study of antibiotic susceptibility of species included 247, 113 and 134 were BMR+ a frequency of 45.7\%. Methicilin-resistant Staphylococcus aureus (MRSA) was predominant (51.3\%). Multivariate logistic regression analysis showed that the main risk factor was antibiotic use (0Ra: 3.2 [1.9 - 5.4]; p-value < 0.01). Chronic renal failure and diabetes were not risk factors for carriage. The other risk factors identified were: hospitalization of more than 7 days (prolonged), Sthaphylococcus aureus infection and male sex. See Tables 4-7.

Table 2. Patients with a positive culture according to inpatient services.

\begin{tabular}{ccc}
\hline \multirow{2}{*}{ Impatients services } & \multicolumn{3}{c}{ POSITIVE CULTURE } \\
\cline { 2 - 3 } & $\mathrm{n}$ & $\%$ \\
\hline Gynaecology obstetric & 5 & 16.1 \\
Pediatric & 2 & 6.5 \\
Reanimation & 8 & 25.8 \\
Internal medecine & 12 & 38.7 \\
Hemodialysis & 4 & 12.9 \\
All & 31 & 100 \\
\hline
\end{tabular}


Table 3. Species isolated according to the type of sample.

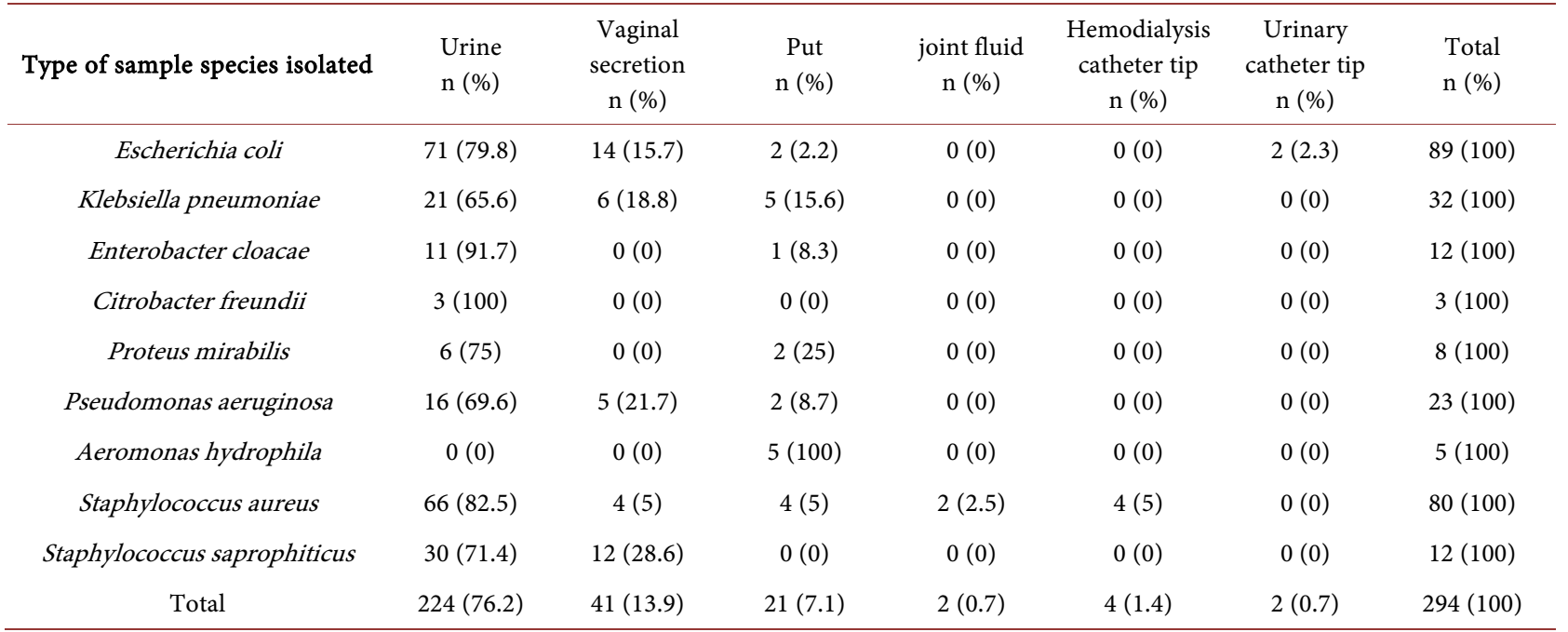

Table 4. Bivariate analysis of risk factors for MRB carriage.

\begin{tabular}{|c|c|c|c|c|c|}
\hline & $\begin{array}{c}\text { Total } \\
\mathrm{N}=247\end{array}$ & $\begin{array}{c}\text { Sensibility } \\
\text { MRB+ } \\
\mathrm{n}=113\end{array}$ & $\begin{array}{c}\text { Sensibility } \\
\text { MRB- } \\
\text { n }=134\end{array}$ & rOR (CI 95\%) & p-value \\
\hline & n (\%) & n (\%) & n (\%) & & \\
\hline Age in years & & & & $3.8(2.2-6.7)$ & $<0.0001^{\circ}$ \\
\hline$\geq 40$ & $80(32.4)$ & $54(47.8)$ & $26(19.4)$ & & \\
\hline$\leq 40$ & $167(67.6)$ & $59(52.2)$ & $108(80.6)$ & & \\
\hline Sex & & & & $2(1.2-3.4)$ & $0.0094^{\circ}$ \\
\hline Male & $102(41.3)$ & $57(50.4)$ & $45(33.6)$ & & \\
\hline Feminine & $145(58.7)$ & $56(49.6)$ & $89(66.4)$ & & \\
\hline Professional activity & & & & $3.1(1.7-5.8)$ & $0.0002^{\circ}$ \\
\hline No renumerating & $179(72.5)$ & $95(84.1)$ & $84(62.7)$ & & \\
\hline Renumerating activity & $68(27.5)$ & $18(15.9)$ & $50(37.3)$ & & \\
\hline Educational level & & & & $2.4(1.4-4.2)$ & $0.02^{\circ}$ \\
\hline Schooled & $72(29.1)$ & $44(28.9)$ & $28(20.9)$ & & \\
\hline No schooled & $175(70.9)$ & $69(61.1)$ & $106(79.1)$ & & \\
\hline Origin & & & & $3.2(1.5-6.8)$ & $0.003^{\circ}$ \\
\hline Inpatient & $36(14.6)$ & $25(22.1)$ & $11(8.2)$ & & \\
\hline Outpatient & $211(85.4)$ & $88(77.9)$ & $123(91.8)$ & & \\
\hline Hospital stay & & & & $15(1.7-136.2)$ & $0.009^{\circ}$ \\
\hline$\geq 7$ & $20(55.6)$ & $15(60.0)$ & $1(9.1)$ & & \\
\hline$\leq 7$ & $16(44.4)$ & $10(40.0)$ & $10(90.9)$ & & \\
\hline $\begin{array}{l}\text { Hospitalization } \\
\text { during the year }\end{array}$ & & & & $2.5(1.5-4.2)$ & $0.0007^{\circ}$ \\
\hline Yes & $98(39.7)$ & $58(51.3)$ & $40(29.9)$ & & \\
\hline No & $149(60.3)$ & $55(48.7)$ & $94(70.1)$ & & \\
\hline
\end{tabular}

osignificative p-value; rOR raw odds ratio; CI confidence interval. 
Table 5. Bivariate analysis of risk factors for MRB carriage.

\begin{tabular}{|c|c|c|c|c|c|}
\hline & Total & $\mathrm{MRB}+$ & MRB- & rOR (CI 95\%) & p-value \\
\hline & n (\%) & n (\%) & n (\%) & & \\
\hline Surgery in 30 days & & & & $2.2(1.2-4)$ & $0.008^{\circ}$ \\
\hline Yes & $61(24.7)$ & $37(32.7)$ & $24(17.9)$ & & \\
\hline No & $186(75.3)$ & $76(67.3)$ & $110(82.1)$ & & \\
\hline Diabetis & & & & $2.1(1.2-3.6)$ & $0.009^{\circ}$ \\
\hline Yes & $79(32.0)$ & $46(40.7)$ & $33(24.6)$ & & \\
\hline No & $168(68.0)$ & $67(59.29)$ & $101(75.4)$ & & \\
\hline Antibiotic in 30 days & & & & $4.1(2.3-7.2)$ & $<0.0001^{\circ}$ \\
\hline Yes & $82(33.2)$ & $56(49.6)$ & $26(19.4)$ & & \\
\hline No & $165(66.8)$ & $57(50.4)$ & $108(80.6)$ & & \\
\hline Injectable treatment & & & & $3.95(1.4-11.2)$ & $0.009^{\circ}$ \\
\hline Yes & $20(8.1)$ & $14(12.4)$ & $5(3.7)$ & & \\
\hline No & $227(91.9)$ & $99(87.6)$ & $129(96.3)$ & & \\
\hline Indwelling surgery & & & & $3.0(1.1-8.1)$ & $0.03^{\circ}$ \\
\hline Yes & $20(8.1)$ & $14(12.4)$ & $6(4.5)$ & & \\
\hline No & $227(91.9)$ & $99(87.6)$ & $128(95.5)$ & & \\
\hline $\begin{array}{c}\text { Spacies (pseudomonas } \\
\text { aeroginosa) }\end{array}$ & & & & $1.1(0.5-2.6)$ & 0.83 \\
\hline Yes & $23(9.3)$ & $11(9.7)$ & $12(9.0)$ & & \\
\hline No & $224(90.9)$ & $102(90.3)$ & $122(91.0)$ & & \\
\hline $\begin{array}{c}\text { Spacies (staphylococcus } \\
\text { aureus) }\end{array}$ & & & & $5.4(3.0-9.7)$ & $0.0001^{\circ}$ \\
\hline Yes & $80(32.4)$ & $58(51.3)$ & $22(16.4)$ & & \\
\hline No & $167(67.6)$ & $55(48.7)$ & $112(83.6)$ & & \\
\hline
\end{tabular}

significative p-value; rOR raw odds ratio; CI confidence interval.

Table 6. Logistic regression of MRB risk factors.

\begin{tabular}{|c|c|c|c|c|c|}
\hline & Total & MRB+ & MRB- & aOR (CI 95\%) & p-value \\
\hline & n (\%) & n (\%) & n (\%) & & \\
\hline Age in years & & & & & 0.25 \\
\hline$\geq 40$ & $80(32.4)$ & $54(47.8)$ & $26(19.4)$ & $1^{\wedge}$ & \\
\hline$\leq 40$ & $167(67.6)$ & $59(52.2)$ & $108(80.6)$ & $1.8(0.6-5.9)$ & \\
\hline Sex & & & & & $0.001^{\circ}$ \\
\hline Male & $102(41.3)$ & $57(50.4)$ & $45(33.6)$ & $1^{\wedge}$ & \\
\hline Feminine & $145(58.7)$ & $56(49.6)$ & $89(66.4)$ & $2.8(1.5-5.1)$ & \\
\hline Professional activity & & & & & 0.26 \\
\hline No renumerating & $179(72.5)$ & $95(84.1)$ & $84(62.7)$ & $1^{\wedge}$ & \\
\hline
\end{tabular}




\section{Continued}

\begin{tabular}{|c|c|c|c|c|c|}
\hline Renumerating activity & $68(27.5)$ & $18(15.9)$ & $50(37.3)$ & $0.3(0.05-2.22)$ & \\
\hline Educational level & & & & & 0.60 \\
\hline Schooled & $72(29.1)$ & $44(28.9)$ & $28(20.9)$ & $1^{\wedge}$ & \\
\hline No schooled & $175(70.9)$ & $69(61.1)$ & $106(79.1)$ & $1.3(0.6-2.5)$ & \\
\hline Origin & & & & & $0.0004^{\circ}$ \\
\hline Inpatient & $36(14.6)$ & $25(22.1)$ & $11(8.2)$ & $1^{\wedge}$ & \\
\hline Outpatient & $211(85.4)$ & $88(77.9)$ & $123(91.8)$ & $5.71(2.2-15.1)$ & \\
\hline Hospital stay & & & & & $<0.0001^{\circ}$ \\
\hline$\geq 7$ & $20(55.6)$ & $15(60.0)$ & $1(9.1)$ & $1^{\wedge}$ & \\
\hline$\leq 7$ & $16(44.4)$ & $10(40.0)$ & $10(90.9)$ & $18.1(9.6-31.1)$ & \\
\hline $\begin{array}{l}\text { Hospitalization } \\
\text { during the year }\end{array}$ & & & & & 0.07 \\
\hline Yes & $98(39.7)$ & $58(51.3)$ & $40(29.9)$ & $1^{\wedge}$ & \\
\hline No & $149(60.3)$ & $55(48.7)$ & $94(70.1)$ & $2.2(0.9-4.1)$ & \\
\hline
\end{tabular}

${ }^{\circ}$ significative p-value; $\wedge$ aOR ajusted odds ratio; $\mathrm{CI}$ confidence interval.

Table 7. Logistic regression of MRB risk factors.

\begin{tabular}{|c|c|c|c|c|c|}
\hline & Total & MRB+ & MRB- & aOR (CI 95\%) & p-value \\
\hline & n (\%) & n (\%) & n (\%) & & \\
\hline Surgery in 30 days & & & & & 0.75 \\
\hline yes & $61(24.7)$ & $37(32.7)$ & $24(17.9)$ & $1^{\wedge}$ & \\
\hline No & $186(75.3)$ & $76(67.3)$ & $110(82.1)$ & $1.4(0.2-11.3)$ & \\
\hline Diabetis & & & & & 0.06 \\
\hline yes & $79(32.0)$ & $46(40.7)$ & $33(24.6)$ & $1^{\wedge}$ & \\
\hline No & $168(68.0)$ & $67(59.29)$ & $101(75.4)$ & $1.7(0.9-2.9)$ & \\
\hline Antibiotic in 30 days & & & & & $<0.001^{\circ}$ \\
\hline yes & $82(33.2)$ & $56(49.6)$ & $26(19.4)$ & $1^{\wedge}$ & \\
\hline No & $165(66.8)$ & $57(50.4)$ & $108(80.6)$ & $3.2(1.9-5.4)$ & \\
\hline Injectable treatment & & & & & 0.50 \\
\hline yes & $20(8.1)$ & $14(12.4)$ & $5(3.7)$ & $1^{\wedge}$ & \\
\hline No & $227(91.9)$ & $99(87.6)$ & $129(96.3)$ & $1.3(0.7-2.5)$ & \\
\hline Indwelling surgery & & & & & 0.62 \\
\hline yes & $20(8.1)$ & $14(12.4)$ & $6(4.5)$ & $1^{\wedge}$ & \\
\hline No & $227(91.9)$ & $99(87.6)$ & $128(95.5)$ & $1.3(0.6-2.5)$ & \\
\hline $\begin{array}{c}\text { Spacies } \\
\text { (staphylococcus aureus) }\end{array}$ & & & & & $0.02^{\circ}$ \\
\hline Yes & $80(32.4)$ & $58(51.3)$ & $22(16.4)$ & $1^{\wedge}$ & \\
\hline No & $167(67.6)$ & $55(48.7)$ & $112(83.6)$ & $5.9(1.3-26.3)$ & \\
\hline
\end{tabular}

${ }^{\circ}$ significative p-value; $\wedge$ aOR ajusted odds ratio; $\mathrm{CI}$ confidence interval. 


\section{Discussion}

The different stages from the sampling to the post analytical were respected according to the standards and recommendations in force [12]-[17].

In this study, the frequency of multidrug resistance bacteria (MRB) was $45.7 \%$. In the majority of cases these were MRSA (51.3\%), EBRC3G (38.9\%) and PAMR (9.7\%). We have not isolated strains of Acinetobacter baumannii. In France, Pierrot S had returned 28.5\% in 2015 [18] while in Morocco, Azmoun S had brought back $25.5 \%$ to the CHU of MARRAKECH in 2016 [17] and Saadaoui M in 2008 had found 19\% to the Hassan II hospital in Settet [14]. Several reasons can explain these results.

Male sex was statistically associated with antibiotic resistance as reported by Pierrot S, in 2015 in France [18], Birgand G and al in 2013 in France [19], MBOYO F and al in 2016 in Morocco [9], then Koujane L in 2011 in Morocco [16]. The involvement of the male sex in the occurrence of BMR is not clearly established despite the unanimity of several authors [10] [15] [18] [20]. In the present study, a statistically significant association was found between hospitalization and BMR carriage. These results were also reported by MBOYO F. et al. 2016 in Morocco [9] and Deguenevo L et al. in Senegal [10]. Normal (sensitive) flora can be replaced by resistant flora (hospital strains) during hospitalization. Invasive manipulations increase the risk of developing MRB [18] [19]. It is thus that in this series patients were treated by injection and had an indwelling catheter.

The impact of the consumption of antibiotics on the occurrence of resistance has been documented [21] [22] [23]. Antibiotics do not induce resistance in themselves, but they lead to the selection of resistant mutants by reducing or even destroying the patient's sensitive normal flora, thus allowing resistant bacteria to proliferate [23]. These MRBs acquired during hospitalization can persist for several months or even years [24]-[31]. This explains the predominance of MRB in our series in patients with a history of hospitalization within the year, surgery within 30 days and antibiotics taken within 30 days. The existence of an underlying pathology such as chronic renal failure, diabetes mellitus; recurrent urinary tract infections and HIV infection in the acquisition of BMRs had been reported by several authors [32] [33] [34]. In our series, diabetes mellitus was statistically associated with a risk of MRB as in the work of Majida $\mathrm{H}$ and al in 2014 [12]. Recurrent urinary tract infections, chronic renal failure and HIV have not been statistically associated with risk factors for the occurrence of resistance to MRB as has been proven in other studies [12] [35] [36]. This can be explained by the small size of our sample.

\section{Conclusion}

Probabilistic antibiotic therapy leads to the selection of MRBs. Visits to hospital patients by community populations lead to the dissemination of these MRBs, first of all SARMs, to the community. Kidney failure is not a risk factor for bac- 
terial resistance. Short hospitalizations and the rational use of antibiotics are effective means of combating this phenomenon.

\section{Confidentiality and anonymity}

The study was carried out with respect for patient anonymity and the confidentiality of information.

\section{Conflicts of Interest}

The authors or anyone who participated in this study declare no conflict of interest.

\section{References}

[1] Carle, S. (2009) La résistance aux antibiotiques: Un enjeu de santé publique important. Pharmacological Reviews, 42, 120-125.

[2] Woodford, N., Turton, J.F. and Livermore, D.M. (2011) Multiresistant Gram-Negative Bacteria: The Role of High-Risk Clones in the Dissemination of Antibiotic Resistance. Microbiology and Molecular Biology Reviews, 35, 736-755. https://doi.org/10.1111/j.1574-6976.2011.00268.x

[3] Bertrand, X., Costa, Y. and Pina, P. (2005) Surveillance de la résistance bactérienne aux antibiotiques dans les bactériémies: Données de l'observatoire national de l'épidémiologie de la résistance bactérienne aux antibiotiques (ONERBA) 1998-2003. Medicine Tropicale, 35, 329.

[4] Trystram, D., Chardon, H., Péan, Y., Delarbre, J., Costa, Y., Maugat, S., et al. (2012) Réseau européen de surveillance de la résistance bactérienne aux antibiotiques (EARS): Résultats 2001-2010 pour la France et place en Europe. Epidemiologisches Bulletin, LV N $317,42-43$.

[5] MacGowan, A. and Macnaughton, E. (2017) Antibiotic Resistance. Medicine Tropicale, 45, 622-628. https://doi.org/10.1016/j.mpmed.2017.07.006

[6] Brun-Buisson, C. (2015) Le dépistage des porteurs de bactéries multirésistantes: Chez quels patients? Annales Françaises d Anesthésie et de Réanimation, 24, 304-314. https://doi.org/10.1007/s13546-014-0940-7

[7] Gérôme, P., Dusseau, J.-Y., Masseron, T. and Bercion, R. (2001) La phase pré-analytique en bactériologie. FEMS Microbiology Reviews, 200, 23-30. https://doi.org/10.1016/S0338-9898(01)80227-4

[8] World Health Organization (2018) Global Antimicrobial Resistance Surveillance System (GLASS) Report: Early Implementation 2017-2018. European Center for Disease Prevention and Control, Stockholm, 1-108.

[9] Mboyo, F.C. (2016) Incidence, facteurs de risque et épidémiologie des bactéries multirésistantes en milieux de réanimation: Étude prospective de six mois à l'HMIMV-Rabat 2016. These de Médecine. Université MOHAMMED V, 140 p.

[10] Déguénonvo, L.F., Traoré, K., Badiane, N.D., Ka, R., Cissoko, Y., Diouf, A., et al. (2016) Résultats d'une enquête d'incidence des cas d'infections nosocomiales à bactéries multirésistantes dans un centre hospitalier à Dakar (Sénégal). Revue Malienne d' Infectiologie et de Microbiologie, 13, 120-127.

[11] Rachel, M., Gabriel, A., Etienne, N., Esther, O.N., Fabien, N.R., Claudette, Y.G., et al. (2014) Activity of Bêta-Lactam Antibiotics and Production of Beta-Lactamases in Bacteria Isolated from Wound Infections in Brazzaville, Congo. African Journal of 
Microbiology Research, 8, 2290-2294. https://doi.org/10.5897/AJMR12.1663

[12] Majida, H. (2014) Les facteurs de risque des infections à BMR au niveau des services de réanimation, CHU Ibn Rochd, Casablanca. Mémoire de Master d’Épidémiologie de Santé Publique. Ecole Nationale de Santé Publique du Royaume de Maroc, 130 p.

[13] Aissaoui, Y., Chouaib, N., Chouikh, C., Rafai, M., Azendour, H., Balkhi, H., et al. (2010) Bactériémies liées aux cathéters veineux centraux: Étude prospective dans une unité de réanimation médicale marocaine. Annales Françaises d Anesthésie et de Réanimation, 50, 7-9. https://doi.org/10.1016/j.annfar.2010.09.011

[14] Saadaoui, M. (2008) La fréquence des bactéries multirésistantes à l'hôpital Hassan II de Settat en 2008. These de pharmacie université Mohamed V, rabat, 121 p.

[15] Laudat, P., Galinier, J.L., Cattoen, C., Ferroni, A., Lamy, B., Courcol, R., et al. (2014) L'accréditation en bactériologie: Enjeux, difficultés et particularités. FEMS Microbiology Reviews, 204, 2530. https://doi.org/10.1016/S1773-035X(14)72442-6

[16] Koujane, L. (2011) Epidemiologie et résistance des BMR à l'hôpital d'instruction Mohamed V de rabat 2011. http://ao.um5s.ac.ma/xmlui/handle/123456789/1851

[17] Azmoun, S. (2016) Epidemiologie de la résistance bactérienne aux antibiotiques au CHU de MARRAKECH. These de medicine, Faculté de médecine et e pharmacie de MARRAKECH, $117 \mathrm{p}$.

[18] Pierrot, S. (2015) Portage de bactéries multirésistantes en structures d'accueil pour personnes âgées: Évaluation d'une politique de dépistage cible en fonction des facteurs de risque. Thèse de Pharmacie, Université de Lorraine, Lorraine, $110 \mathrm{p}$.

[19] Birgand, G. and Lucet, J.C. (2013) Politique de dépistage des BMR: Quand et qui faut-il dépister? Revue Française des Laboratoires, 453, 29-39. https://doi.org/10.1016/S1773-035X(13)72079-3

[20] Djuric, O., Jovanovic, S., Stosovic, B., Tosic, T., Jovanovic, M. and Markovic-Denic, L. (2016) Antimicrobial Resistance of Selected Invasive Bacteria in a Tertiary Care Center: Results of a Prospective Surveillance Study. Journal of Infection, 10, 1325-1331. https://doi.org/10.3855/jidc.7695

[21] Ouédraogo, A.S., Somé, D.A., Dakouré, P.W.H., Sanon, B.G., Birba, E., Poda, G.E.A., et al. (2011) Profil bactériologique des infections du site opératoire au centre hospitalier universitaire Souro Sanou de Bobo Dioulasso. Medicine Tropicale, 71, 49-52.

[22] Rakotovao-Ravahatra, Z.D., Randriatsarafara, F.M., Rasoanandrasana, S., Raverohanta, L. and Rakotovao, A.L. (2017) Phénotypes de résistance des souches d'Escherichia coli responsables d'infection urinaire au laboratoire du Centre Hospitalo-Universitaire de Befelatanana Antananarivo. The Pan African Medical Journal, 26, 5-9. https://doi.org/10.11604/pamj.2017.26.166.11828

[23] Monnet, D. (2014) Consommation d'antibiotiques et résistance bactérienne. Annales Françaises d Anesthésie et de Réanimation, 60, 13-17.

[24] Rabaud, C. (2013) Réflexion sur les mesures pratiques qui doivent être envisagées pour préserver ce bien inestimable que sont les antibiotiques et lutter contre l'extension progressive des résistances bactériennes. Tropical Medicine and Infectious Disease, 43, 97-99. https://doi.org/10.1016/j.medmal.2013.02.012

[25] Ruppé, É. and Andremont, A. (2013) Le microbiote intestinal est l'avenir de la multirésistance bactérienne. The Journal of Antibiotics, 15, 166-177.

https://doi.org/10.1016/j.antinf.2013.08.002

[26] Cattoen, C. (2015) Persistance du portage de bactéries multirésistantes après la réanimation. Annales Françaises d Anesthésie et de Réanimation, 24, 249-255. 
https://doi.org/10.1007/s13546-015-1048-4

[27] Haverkate, M., Derde, L. and Brun-Buisson, C. (2014) Duration of Colonization with Antimicrobial-Resistant Bacteria after ICU Discharge. Intensive Care Medicine, 40, 564-571. https://doi.org/10.1007/s00134-014-3225-8

[28] Apisarnthanarak, A., Bailey, T. and Fraser, V. (2009) Duration of Stool Colonization in Patients Infected with Extended-Spectrum Betalactamase Producing Escherichia coli and Klebsiella pneumoniae. Clinical Infectious Diseases, 46, 1322-1323. https://doi.org/10.1086/533475

[29] O’Fallon, E., Gautam, S. and D'Agata, E. (2009) Colonization with Multidrug-Resistant Bacteria: Prolonged Duration and Frequent Cocolonization. Clinical Infectious Diseases, 48, 1375-1381. https://doi.org/10.1086/598194

[30] Mattner, F., Biertz, F. and Ziesing, S. (2010) Long-Term Persistence of MRSA in Readmitted Patients. Infection, 38, 363-371. https://doi.org/10.1007/s15010-010-0038-8

[31] Robisek, A., Beaumont, J. and Peterson, L. (2009) Duration of Colonization with Methicillin-Resistant Staphylococcus aureus. Clinical Infectious Diseases, 48, 910-913. https://doi.org/10.1086/597296

[32] Scanvic, A., Denic, L., Gaillon, S. and Giry, P. (2010) Duration of Colonizationby Methicillin-Resistant Staphylococcus aureus after Hospital Discharge and Risk Factors for Prolonged Carriage. Clinical Infectious Diseases, 32, 1393-1398. https://doi.org/10.1086/320151

[33] Larsson, A.K., Gustafsson, E. and Nilsson, A.C. (2011) Duration of Methicillin-Resistant Staphylococcus aureus Colonization after Diagnosis: A Four-Year Experience from Southern Sweden. Scandinavian Journal of Infectious Diseases, 43, 456-462. https://doi.org/10.3109/00365548.2011.562530

[34] Marmouch, H., Aouam, A., Toumi, A., Loussaief, C. and Chakroun, M. (2014) P116 Diabète et bactéries multirésistantes: Analyse de 95 cas. Diabetes \& Metabolism, 40, 57. https://doi.org/10.1016/S1262-3636(14)72408-5

[35] Estournet, C. (2013) Acquisition d'entérobactéries productrices de bétalactamases à spectre élargi au cours des trois premiers mois de transplantation rénale: Étude épidémiologique et impact clinique. Nephrology, 10, 3-8.

[36] Ayzac, L., Bisaccia, V., Chatelet, C., Darre-Plat, S., Gardes, S., Garcia, E.L., et al. (2017) Protocole du réseau de surveillance des infections en hémodialyse. Journal of Nephrology, 87, 62-64. 